\title{
Necrotizing fasciitis caused by a primary appendicocutaneous fistula
}

\author{
Makoto Takeda $\cdot$ Yukihiro Higashi $\cdot$ \\ Tuyoshi Shoji · Takanori Hiraide · Hirotoshi Maruo
}

Received: 28 January 2011 / Accepted: 5 July 2011 / Published online: 10 February 2012

(C) The Author(s) 2012. This article is published with open access at Springerlink.com

\begin{abstract}
We report a case of necrotizing fasciitis in the loin of a 76-year old man with several coexisting or past health issues, including diabetes mellitus, hypertension, alcohol-related liver cirrhosis, gastrectomy for gastric cancer, subarachnoid hemorrhage, normal pressure hydrocephalus, and cerebral infarction. Incision of the necrotizing fasciitis was successful, but it revealed an appendicocutaneous fistula; thus, we performed appendectomy and fistulectomy. We think that the necrotizing fasciitis was caused by appendicitis perforation involving the retroperitoneum, inducing the formation of an appendicocutaneous fistula. Necrotizing fasciitis and appendicocutaneous fistulae are rare complications of appendicitis. Moreover, to our knowledge, this is the first report of fluoroscopic examination demonstrating that a primary appendicocutaneous fistula had caused necrotizing fasciitis. Our search of the literature found 12 cases of necrotizing fasciitis caused by preoperative appendicitis. We discuss the characteristics and findings of these cases.
\end{abstract}

Keywords Necrotizing fasciitis - Appendicocutaneous fistula $\cdot$ Appendicitis

\section{Introduction}

Necrotizing fasciitis is a potentially fatal soft tissue infection associated with high mortality $(6-76 \%)$ [1]; the necessity of early aggressive surgical debridement for necrotizing fasciitis is well documented. When a pathogen

M. Takeda $(\varangle) \cdot$ Y. Higashi · T. Shoji · T. Hiraide · H. Maruo Department of Surgery, Shizuoka City Shimizu Hospital, 1231 Miyakami, Shimizu-Ku, Shizuoka 424-8636, Japan e-mail: takedamakoto1977@yahoo.co.jp enters the subcutaneous space, necrotizing fasciitis can occur. Although appendicitis is one of the soft tissue injuries included in its etiology, appendicitis resulting in necrotizing soft tissue infection is extremely rare and often fatal [2]. We report a case of a primary appendicocutaneous fistula causing necrotizing fasciitis, which is an exceptionally rare event [3].

\section{Case report}

The patient was a 76-year-old man whose chief complaint was difficulty in walking and pain in his right loin. His coexisting disorders included diabetes mellitus, hypertension, and alcoholic liver cirrhosis. He also had a history of gastrectomy for gastric cancer, subarachnoid hemorrhage, normal pressure hydrocephalus, and cerebral infarction. On admission, his body temperature was $35.9^{\circ} \mathrm{C}$; blood pressure, $113 / 80 \mathrm{mmHg}$; and pulse rate, 95 beats/min. He reported tenderness in his right loin, but there were no reddish areas or swelling. His laboratory data on admission were as follows: white blood cell count, $460 \times 10^{2} / \mu 1$ (neutrophils: 98.5\%); hemoglobin, $7.5 \mathrm{~g} / \mathrm{dl}$; creatine, 3.5 $\mathrm{mg} / \mathrm{dl}$ and C-reactive protein, $25.7 \mathrm{mg} / \mathrm{dl}$. Abdominal computed tomography (CT) showed gas and fluid collection extending from the subcutaneous layer of his right loin to his retroperitoneal cavity (Fig. 1). Based on these findings, we diagnosed necrotizing fasciitis. No connection was found between the necrotizing fasciitis and the gut and his appendix was not swollen. Therefore, a $10-\mathrm{cm}$ incision was made in his right loin. Pus and foul-smelling gas were released, and the subcutaneous fat was debrided. Bacterial culture of the pus grew Peptostreptococcus micros, Peptostreptococcus sp., Prevotella disiens, and Escherichia coli. Antibiotic sensitivity tests for meropenem hydrate and 


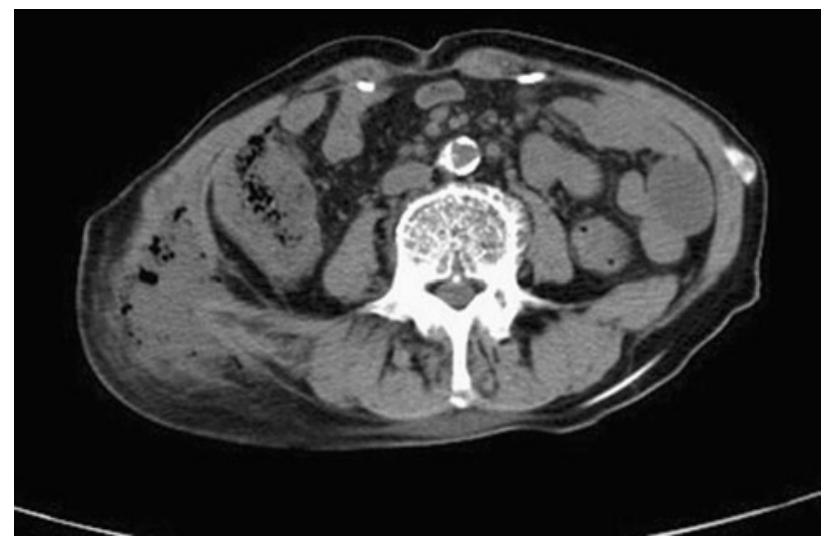

Fig. 1 Abdominal computed tomography scan (horizontal image) showed gas and fluid collection from the subcutaneous layer to the retroperitoneal cavity, with inflammation extending into the adjacent soft tissue near the loin

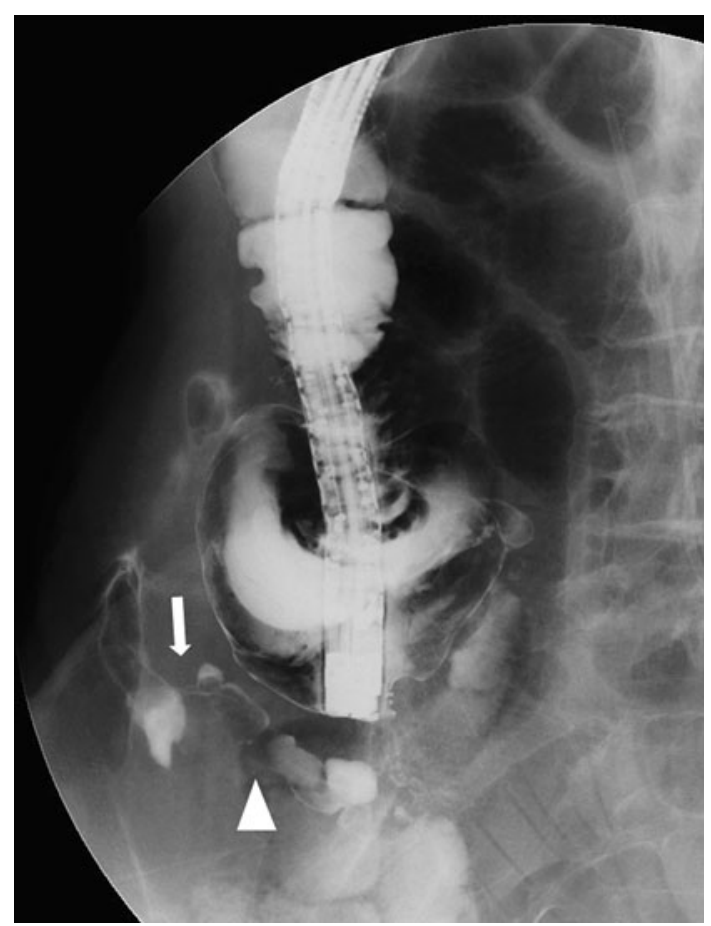

Fig. 2 Fluoroscopic-aided colonoscopy showed the fistula (arrow) enhanced between the appendix (arrowhead) and the incised tissue

clindamycin hydrochloride were positive. We irrigated the incised tissue and gave systematic antibiotic therapy (meropenem hydrate: $1 \mathrm{~g} /$ day, clindamycin hydrochloride: $1.2 \mathrm{~g} /$ day) for 10 days. His inflammatory response improved; however, the underlying cause of his condition could not be investigated effectively because he suffered epileptic seizures. About 3 months after his admission, sordes were discharged from the affected body part. Subsequently, an appendicocutaneous fistula was revealed by fluoroscopyaided colonoscopy (Fig. 2). An open laparotomy revealed strong adhesions between the terminal ileum and retroperitoneum. We found that the distal end of the vermiform appendix had adhered to the retroperitoneum and a fistula had formed. Thus, we performed appendectomy and fistulectomy. The pathohistological diagnosis was chronic acute phlegmonous appendicitis.

His postoperative course was uneventful; however, on postoperative day 35 , a urinary tract infection developed and methicillin-resistant staphylococcus aureus sepsis ensued, resulting in the death of multiple organ failure on postoperative day 48 .

\section{Discussion}

Necrotizing fasciitis is a rare soft tissue infection, which involves the superficial fascia, subcutaneous fat, and deep fascia. Giuliano et al. divided necrotizing fasciitis into two distinct groups, based on his analysis of bacteriologic culture results obtained from affected patients: Type 1, which is polymicrobial and involves non-group A streptococci plus anaerobes and/or facultative anaerobes and also often involves enterobacteriaceae; Type 2, also known as hemolytic streptococcal gangrene, in which the pathogen population is composed of group A $\beta$-hemolytic streptococci alone or in combination with a staphylococcus bacterium [2]. Necrotizing fasciitis can occur in any region of the body, but is found most commonly in the abdominal wall, extremities, and perineum. Involvement of the abdominal wall is usually a postoperative complication of abdominal surgery. Its reported causes include appendicitis, colocutaneous fistula, incarcerated hernia, perforated viscus, renal calculi after abdominal injury, and postoperative complications $[1,2,4]$. The case in this report was classified as type 1 and involved necrotizing fasciitis as a preoperative complication of appendicitis. We found only 12 case reports of patients with necrotizing fasciitis caused by appendicitis published in the English literature and cited in Pub Med (Table 1) [3, 5-15]. Four of these patients were male and nine, female, and their ages ranged from 28 to 85 -years old (mean age: 66-years old). Seven of the 12 patients had a significant medical history $(53.8 \%)$. It is evident that the disease occurs more frequently in patients with complications, but it can even in young, healthy individuals. Four $(30.8 \%)$ of the patients died, reinforcing that the condition is associated with high mortality.

A diagnosis of necrotizing fasciitis is primarily based on the clinical and physical examinations. Patients complain of severe pain, and the characteristic examination features include edema and tenderness extending beyond the limits of cutaneous erythema, crepitus, and skin vesicles. Our patient did not complain of the typical symptoms so diagnosis was difficult using only clinical and physical 
Table 1 Cases of necrotizing fasciitis caused by preoperative appendicitis reported in the English literature

\begin{tabular}{|c|c|c|c|c|c|c|c|}
\hline No. & Author & Year & Sex & Age & Medical history/coexisting disease & Appendix condition & Results \\
\hline 1 & Mazza [5] & 1987 & Female & 59 & None & Perforated appendicitis & Death \\
\hline 2 & Guirguis [6] & 1989 & Female & 80 & $\begin{array}{l}\text { Atrial fibrillation, hypertension, } \\
\text { non-insulin-dependent diabetes, } \\
\text { prescribed four drugs }\end{array}$ & $\begin{array}{l}\text { Gangrenous appendix in an } \\
\text { incarcerated femoral hernia }\end{array}$ & Alive \\
\hline 3 & Jacobs [7] & 1993 & Female & 44 & Not described & Perforated appendicitis & Alive \\
\hline 4 & Gerber [8] & 1994 & Male & 85 & Alzheimer's dementia & Perforated appendicitis & Alive \\
\hline 5 & Bobrow [9] & 1996 & Male & 63 & $\begin{array}{l}\text { Hypertension, congestive heart } \\
\text { failure, depression,insulin- } \\
\text { requiring diabetes mellitus }\end{array}$ & $\begin{array}{l}\text { Perforated appendicitis } \\
\text { with abscess formation }\end{array}$ & Death \\
\hline 6 & Groth [10] & 1999 & Female & 49 & Hypertension & Perforated appendicitis & Alive \\
\hline 7 & Harwant [11] & 2001 & Female & 66 & Not described & Phlegmonous appendicitis & Death \\
\hline 8 & Awe [3] & 2003 & Female & 28 & Not described & $\begin{array}{l}\text { Perforated appendicitis with } \\
\text { an appendicocutaneous fistula }\end{array}$ & Alive \\
\hline 9 & Mukoyama [12] & 2003 & Male & 77 & Depression & Necrotizing appendicitis & Alive \\
\hline 10 & Marron [13] & 2005 & Female & 67 & Not described & $\begin{array}{l}\text { Incarceration of an inguinal hernia } \\
\text { containing the appendix alone } \\
\text { (Amyand's hernia) }\end{array}$ & Alive \\
\hline 11 & Penninga [14] & 2006 & Female & 33 & None & Perforated appendicitis & Alive \\
\hline 12 & Chen [15] & 2010 & Female & 76 & $\begin{array}{l}\text { Congestive heart failure, chronic } \\
\text { obstructive pulmonary disease, } \\
\text { chronic renal insufficiency }\end{array}$ & $\begin{array}{l}\text { Perforated appendicitis with } \\
\text { abscess formation }\end{array}$ & Alive \\
\hline 13 & Our case & 2010 & Male & 76 & $\begin{array}{l}\text { Diabetes mellitus, alcoholic liver } \\
\text { cirrhosis, hypertension, cerebral } \\
\text { infarction, subarachnoid hemorrhage, } \\
\text { normal pressure hydrocephalus, } \\
\text { gastric cancer }\end{array}$ & $\begin{array}{l}\text { Perforated appendicitis with an } \\
\text { appendicocutaneous fistula }\end{array}$ & Death \\
\hline
\end{tabular}

examinations; however, the CT examination is very useful for confirming the diagnosis of necrotizing fasciitis.

Kjellman defined an appendiceal fistula as the primary perforation of the appendix into an adjacent hollow viscus or the skin and excluded fistulae resulting as sequelae of surgically treated appendicitis [16]. The bladder is the organ most commonly associated with appendix fistulae. Appendicocutaneous fistulae are a rare form of enterocutaneous fistulae, and very few cases have been reported $[17,18]$. We did not investigate the cause of our patient's condition, but concentrated on treating his necrotizing fasciitis and many complications. Based on the bacterial culture results and the presence of a fistula, we assume that acute appendicitis perforated the retroperitoneum and formed an appendicocutaneous fistula, resulting in necrotizing fasciitis. Considering the high rate of complications shown in Table 1, we speculate that our patient's state of ill health predisposed to the acute appendicitis causing the fistula and necrotizing fasciitis. Prompt incision and drainage of the collected fluid and antibiotics is considered the best treatment strategy. The cause of necrotizing fasciitis must be investigated after early debridement of all necrotic tissue and drainage of pus.

In conclusion, appendicocutaneous fistula induced by appendicitis perforating the retroperitoneum is a rare cause of necrotizing fasciitis. Surgical debridement should be performed for the necrotizing fasciitis, the cause of which must be investigated after the patient's condition has improved. Fluoroscopic-aided colonoscopy is very useful for investigating the cause of necrotizing fasciitis. Acute appendicitis is one of the most common diseases encountered in clinical practice; however, we should bear in mind that unusual complications can occur, such as necrotizing fasciitis and gangrenous intrathoracic appendicitis caused by incarceration of diaphragmatic hernia, as reported by Schellhaas et al. [19].

Open Access This article is distributed under the terms of the Creative Commons Attribution License which permits any use, distribution, and reproduction in any medium, provided the original author(s) and the source are credited.

\section{References}

1. McHenry CR, Piotrowski JJ, Petrinic D, Malangoni MA. Determinants of mortality for necrotizing soft-tissue infections. Ann Surg. 1995;221:558-63.

2. Green RJ, Dafoe DC, Raffin TA. Necrotizing fasciitis. Chest. 1996;110:219-29.

3. Awe JA, Soliman MA, Gourdie RW. Appendico-cutaneous fistula presenting clinically as right loin necrotizing fasciitis: a case report. Int Surg. 2003;88:121-5. 
4. Elliott DC, Kufera JA, Myers RA. Necrotizing soft tissue infections. Risk factors for mortality and strategies for management. Ann Surg. 1996;224:672-83.

5. Mazza JF Jr, Augenstein JS, Kreis DJ Jr. Necrotizing fasciitis: a rare complication of appendicitis. South Med J. 1987;80:1197-8.

6. Guirguis EM, Taylor GA, Chadwick CD. Femoral appendicitis: an unusual case. Can J Surg. 1989;32:380-1.

7. Jacobs PP, van der Sluis RF, Tack CJ, Wobbes T. Necrotising fasciitis of the lower limb caused by undiagnosed perforated appendicitis, which necessitated disarticulation of the hip. Eur J Surg. 1993;159:307-8.

8. Gerber GS, Guss SP, Pielet RW. Fournier's gangrene secondary to intra-abdominal processes. Urology. 1994;44:779-82.

9. Bobrow BJ, Mohr J, Pollack CV Jr. An unusual complication of missed appendicitis. J Emerg Med. 1996;14:719-22.

10. Groth D, Henderson SO. Necrotizing fasciitis due to appendicitis. Am J Emerg Med. 1999;17:594-6.

11. Harwant S, Borhan TA, Sivakumar S, Jeevanan J. Knee crepitus from an unusual source. Med J Malaysia. 2001;56:98-9.

12. Mukoyama S, Mukai M, Yasuda S, Oida Y, Himeno S, Nishi T, et al. A successfully treated case of severe necrotizing fasciitis caused by acute appendicitis: a case report. Tokai J Exp Clin Med. 2003;28:139-43.
13. Marron CD, Khadim M, McKay D, Mackle EJ, Peyton JW. Amyand's hernia causing necrotising fasciitis of the anterior abdominal wall. Hernia. 2005;9:381-3.

14. Penninga L, Wettergren A. Perforated appendicitis during nearterm pregnancy causing necrotizing fasciitis of the lower extremity: a rare complication of a common disease. Acta Obstet Gynecol Scand. 2006;85:1150-1.

15. Chen CW, Hsiao CW, Wu CC, Jao SW, Lee TY, Kang JC. Necrotizing fasciitis due to acute perforated appendicitis: case report. J Emerg Med. 2010;39:178-80.

16. Skaane P. Spontaneous appendicocutaneous fistula: report of a case and review of the literature. Dis Colon Rectum. 1981;24:550-4.

17. Walker LG Jr, Rhame DW, Smith RB III. Enteric and cutaneous appendiceal fistulae. Arch Surg. 1969;99:585-8.

18. Kjellman T. Appendiceal fistulae and calculi; review of the literature and a report of three cases. Acta Chir Scand. 1957;113: 123-39.

19. Schellhaas E, Döbler O, Kroesen AJ, Buhr HJ, Hotz HG. Gangrenous intrathoracic appendicitis, a rare cause of right-sided chest pain: report of a case. Surg Today. 2010;40:874-7. 